This item was submitted to Loughborough's Research Repository by the author.

Items in Figshare are protected by copyright, with all rights reserved, unless otherwise indicated.

\title{
Balkans and Baltics: on migration as a factor of regional peripheralization
}

PLEASE CITE THE PUBLISHED VERSION

https://doi.org/10.1080/19448953.2018.1532684

PUBLISHER

(C) Taylor \& Francis (Routledge)

VERSION

AM (Accepted Manuscript)

PUBLISHER STATEMENT

This is an Accepted Manuscript of an article published by Taylor \& Francis in Journal of Balkan and Near Eastern Studies on 4 December 2018, available online:

http://www.tandfonline.com/10.1080/19448953.2018.1532684.

\section{LICENCE}

CC BY-NC-ND 4.0

\section{REPOSITORY RECORD}

Lulle, Aija. 2018. "Balkans and Baltics: On Migration as a Factor of Regional Peripheralization". Loughborough University. https://hdl.handle.net/2134/35557. 


\title{
Balkans and Baltics: On Migration as a Factor of Regional Peripheralization
}

\author{
Aija Lulle \\ Geography and Environment, Loughborough University, United Kingdom
}

\begin{abstract}
In this paper I propose a critical comparative reflection on migration as a factor of peripheralization processes in the Western Balkan and Baltic regions. In their respective geographical positions, the Western Balkans and the Baltics stand at different ends of the European map: south-east and north-east. Regarding their historical and political positions, however, these are very diverse: the Western Balkans were part of Yugoslavia (except Albania) while the Baltic republics (Estonia, Latvia, Lithuania) were annexed to the Soviet Union after the Second World War. Currently, two Western Balkan countries - Slovenia and Croatia - are already members of the European Union, as the three Baltic countries are, while the rest of Western Balkans are not. I argue that apart from economic and geographical factors, usually taken into account in describing peripheries and cores, migration processes and discourses powerfully construct some places as dynamically moving towards a 'core' while others remain confined to a 'periphery'. By paying special attention to 'scientific discourses', I aim to broaden our understanding of theories and practices of peripheralization, where migration tends to be under-theorized.
\end{abstract}

\section{Introduction}

If we look at a map of Europe, the Baltic countries and the Western Balkans stand at two extremes, north-east and south-east with huge distances and many different countries in between. These regions are rarely compared, and few case studies exist so far, despite the fact that there could be a multitude of historical, economic and political factors at stake to compare. In this paper I will focus on issues of migration, and more specifically on the discourses that surround and permeate the notion of migration in these regions. Such comparisons on migration discourses or practices in these regions are thus far very rare. ${ }^{1}$ But before I approach these necessarily entangled discursive constructs, I want to briefly state my understanding of the notion of 'regions' in this paper.

One of the most influential thinkers on regions and periheralization, Anssi Paasi argues that regions are socially constructed, and as such should be understood in socio-spatial terms. ${ }^{2}$ Moreover, regions are 'products that have been constructed in relation to specific criteria'. ${ }^{3}$ These representations are always related to broad global relations within which we often talk about development and migration. Through such a socio-spatial lens, the Baltics and the Balkans are not simply clusters of small states at the outer borders of the European Union, but interwoven in the globalization of neoliberal capitalism, world urbanization and other global trends. Although these geopolitical factors are pertinent and contextual, they do not fix some places into peripheries and nothing more. And, although political power relations, along with cultural representations such as 
'Balkanization' or 'Eastern Europe' form discursive fields about rather weak and peripheral regions, ${ }^{4}$ I want to leave these issues in the contextual background and concentrate on the role played by migration in peripheralization. My main focus is to bring the modes of representation of migration into the fore of my analysis of peripheralization processes.

Therefore the underpinning question of this paper is how these modes of representation of migration play a role in the construction of peripheralization. Relatedly, how do these modes construct regions (and countries within regions) as more 'peripheral' or more 'core' oriented?

From the international migration point of view, prosperous core states are more associated with the process of immigration: the economy is developing, there is a need for more workforce, and migrants tend to move to places where they have better economic opportunities. Emigrant countries, one could assume, represent the opposite situation, associated with the economic and geographic periphery. On a national scale, cores and peripheries can be well seen through the process of urban drift: in both our case-study regions there have been clear urbanization processes. Moreover, in both the Western Balkans and Baltics internal and international migration are complexly interlinked: populations have been moving towards the capital city or other urban centres, and in some cases emigration was as the next step after internal migration pathways, whereas in other cases international migration prefigures internal migration when returnees originating in peripheral rural regions resettle in urban destinations. ${ }^{5}$

Accordingly, in the analytical sections I will focus on the above-mentioned modes of representation - emigration, depopulation, regional migration and immigration - and analyse migration in a dynamic way as shifting towards cores or peripheries as well as reshaping the definition of cores and peripheries in the process. First, however, I briefly present my theoretical framework and a note on methodology.

\section{Theorising peripheraliztion and migration}

I take Paasi's arguments on regions and peripheralization as a starting-point. He encourages researchers on regionalization and peripheralization to ask a question: 'Who and what constructs regions, through what associations/networks and for what purposes?' and then reminds us that 'answers are always contextual'. ${ }^{6}$ There are many factors which have been taken into account by the various scholars who define and analyze peripheralization processes. Global factors are usually grounded in economic geography: uneven development within and between regions and states, which are lagging behind the performance as measured from the centre, the core. These economic factors are usually multiple and complex, involving macroeconomic performance, transport connectivity, accumulated capital and so on.

Regions are often simply defined and described as statistical or administrative, but they need to be critically understood as 'social spatialization'; namely, as socially constructed spaces embedded in power relations, which can in turn be expressed in core-periphery frameworks. Peripheralization in the Western Balkans and the Baltics often goes hand-in-hand with polarization. The latter, in its basic meaning, is understood as growing differences and inequalities economically, socially, spatially - both between countries and, more particularly, also internally. Despite the small size of all the Baltic and Western Balkan states, one of the most remarkable 
features of recent decades has been their ongoing socio-economic spatial polarization, and ruralurban and inter-regional migration have been intrinsic to this process. Both regions underwent profound transformations from command to market economy, privatization, growth in metropolitan and peri-urban areas; ${ }^{7}$ and both, albeit at different times, sought access to the European Union. The Baltic states, as well as Slovenia, joined in 2004, Croatia in 2013, while the other Western Balkan states stand in a somewhat uncertain position in 2018. Hence peripheralization and polarization characterize the broader geographies of post-socialist transformation in these two groups of countries. $^{8}$ In addition, in the EU's multi-level governance framework and especially in the Eurozone, the core countries are seen as more competitive internationally as they have higher levels of productivity. By contrast, reflecting their subjection to fiscal discipline measures, peripheries have high external and public debts, as in case of six Western Balkan countries, which Bartlett and Prica call the 'super-periphery'. ${ }^{9}$ However, beyond economic parameters, the phenomenon of peripheralization also needs to be linked to historical and ongoing processes of migration.

For a long time in migration studies, in fact since the very beginning, emigration has been associated with the status of a periphery, while immigration has generally correlated with core regions of economic activities and better wages. Return migration, for its part, does not have such clear connotations. Return can be interpreted as failure to achieve pre-set goals in an immigration country, or as linked to certain life stages, for instance, after retirement. On the other hand, return can also be seen as led by innovation, and the desire to invest knew knowledge and skills in the country of origin. ${ }^{10}$ Hence, to some extent return does imply peripheralization: either as the place where 'failed migrants' return to, or as a peripheral region/country where returning migrants can potentially carry some developmental stimulus. Transit migration, however, is a relatively new term which can also be directly linked to peripeheralization processes, especially if we see transit migration (and the ways in which regions and countries deal and cannot deal with it) through a migration governance perspective, dictated by the core.

One of the clearest recent descriptions of periphery-core relations belongs to King. ${ }^{11}$ Through a concise review of the development of the core-periphery framework, beginning with dependency theorists ${ }^{12}$ and world systems theory ${ }^{13}$ he then focuses on a lesser-known but highly relevant study of underdevelopment in Europe produced by Seers et al. in the 1970s. ${ }^{14}$ Drawing on Selwyn's broad reflections on periphery, ${ }^{15}$ King distinguishes the following characteristics. Peripheries lack effective control over many kinds of resources and innovations, whilst internal linkages within a periphery are weak. Moreover, information flows are usually from core to periphery and likewise humans: they migrate from periphery to core regions and economies. Although these observations belong to the 1970s they actually serve very well when reflecting on the social construction of peripheralization at the beginning of the $21^{\text {st }}$ century, when other aspects of broad Europeanization processes are quite different. So, peripheralization can be succinctly defined as 'a loss of capacities of actors and institutions to act', ${ }^{16}$ while hierarchies of cores and peripheries relegate the latter, as Merje Kuus has aptly summarized, to 'places of lower rank' ${ }^{17}$

Both the Baltic and Balkan regions, to a certain extent, also suffer another side-effect of emigration and post-socialist transformations - that of depopulation and declining birth rates. These may also result in the phenomenon of 'brain drain', reflecting limited possibilities for highly educated young people, including many recent graduates, to finding rewarding work in their home 
countries, encouraging them to leave in search of better income, employment and career opportunities.

In summing up the theoretical approach for this paper, I will forefront modes of representation of migration against the background of a discursive construction of peripheries as 'lagging behind', 'emptying,' and 'brain draining' in these two case-study regions. Simultaneously I will stay alert to alternative representations of processes of immigration and regional migration, and potentialities for development as positive counter-constructions to peripheralization. One should also keep in mind that representation is constructed by certain schools of thoughts which may, but most often do not, stem from the regions of interest of this paper. From the outside, scholars from the core regions may routinely describe these regions as peripheral, 'east', with specific contextual meanings of Balkanization ${ }^{18}$ or post-Soviet influences. ${ }^{19}$ Yet, different narratives emerge as well. For instance, most recently Estonian researcher Maarja Saar challenged the overwhelming portrayal of Baltic emigration as labour migration and showed that lifestyle concerns can be prime motives for emigrants and returnees too. ${ }^{20}$ This invites us to be careful and critical of how migration, as a peripheralization factor, is evaluated differently on various spatial scales, and from different viewpoints.

\section{Note on methodology}

Paasi notes that peripheralization is constructed through material and non-material elements, media representations and political communication, ranking and recommendations, as well as everyday experiences. ${ }^{21}$ However, he emphasizes that it also blends in scientific analysis, and this 'scientific blend' is the main focus of this paper. Scientific writing, like the media but for different audiences and using different methods, can deploy the centre-periphery axis as an analytical frame at different scales. ${ }^{22}$ Such an approach is a strategic mechanism in the construction of meaning of a periphery associated or implied with migration processes. Simultaneously, such periphery-ingrained representations further shape the geographical imagination.

Scientific representation can be made in various ways: if not using explicit theories of peripheralization, representations may draw on economic development theories, migration theories imbued with development ideas, notions of regions 'lagging behind', and of places and countries lacking capacities to act and innovate due to the draining effects of migration processes, thus emphasizing their peripherality. These narratives and discourses evolve and reshape themselves over time.

In order to trace modes of representation and their dynamics, I firstly I skimmed through a large corpus of scientific publications during the past fifteen years to get an overview of themes used when representing migration processes in the two regions. Secondly, I created a sample of 54 research papers and ordered them thematically according to the most prominent issues in both regions: (1) emigration within an overarching 'East-West' framework; (2) depopulation and brain drain; (3) specifically for the Western Balkans, transit migration and irregular border crossing; (4) weak development, notably for return migration and immigration.

Naturally, some of these themes and representations are intermingled. I also crossreferenced the relative importance of these themes with other indicators such as statistical data and 
media references. These four themes constitute most of the rest of this paper, following a brief historical-contextual overview.

\section{Brief historical overview of migration processes}

To understand the migration flows in the Balkans and Baltics, we need to briefly review the history of migration in these regions. ${ }^{23}$ Before the First World War the most desirable destination of the migrants from the Balkans was the USA; whilst from the Baltics, the USA, Latin America and Russia were preferred. Two different processes took place: forced migration, usually due to conflicts prior to the creation of nation-states and Yugoslavia emerged, and migration for economic reasons.

During the interwar period the European core economies, especially France and Germany, were attractive to both Baltic and Balkan migrants, often including the middle class, students and those in creative professions. After the Second World War, large volumes of forced migration in the form of deportations from the Baltics took place, along with refugee streams towards Western Europe, some of the latter then re-distributed to other Western countries globally. At least 200,000 from the three Baltic states were deported, mainly in two waves in 1941 and 1949; and even more escaped as refugees. 'Free' emigration was severely restricted to individuals, with the exception of Soviet Jews, until the end of the Soviet Union in the late 1980s.

After the Second World War, socialist Yugoslavia did not open its borders until 1963-64, after which West Germany became the main target for emigrants. Between 1963 and 1981, around 4 per cent of the total population left the country. ${ }^{24}$ Return migration also took place: from 1981, about 280,000 returned but up to an estimated one-third of the returnees went abroad again, unable to adapt to the socialist system any more. Albania, on the other hand, did not allow emigration; as a consequence, its population grew fast: from 1.2 million in 1950 to 3.2 million in $1989 .{ }^{25}$

While in some parts of former Yugoslavia, especially in Slovenia and also Croatia, migration was less restricted and people could move also to 'Western' countries, cross-border mobility was anyway controlled with other means, including currency exchange rates. However, emigration was almost completely impossible from Albania; in fact, it was effectively the most isolated country in Europe throughout the second part of the $20^{\text {th }}$ century, until around $1990{ }^{26}$ Emigration was also severely restricted from the Baltic states during Soviet times, and even travelling to other socialist countries was rather limited and privileged, often as a reward for good work in building communist futures. Yugoslavia and the Western Balkans were seen as more developed, with a better climate and amenities that appealed to northerners from the Baltic region along with access to better goods produced outside the Soviet Union. In the meantime, there was considerable regional migration within former Yugoslavia, the Baltic states and the wider USSR, including exchanges of students and workers in the creative professions. However, nowadays the realities of mixed emigration from the Western Balkans - a recent history of forced migration due to wars, and continuing economic reasons to emigrate - pose the biggest challenges for the region's development, while population decline is an issue overshadowing the future development of the Baltics. As the result, emigration has profoundly changed these countries and regions during past two decades. Besides, the process of migration itself has changed over time, 'maturing' from 
temporary to more permanent forms in the Western Balkans, and especially in Albania where the scale and suddenness of mass emigration have been greatest. ${ }^{27}$

\section{East-West migration}

I begin with the Baltics. It is evident that local migration scholars were mainly preoccupied with the central statistical representation of the volume and structure of migration flows from the Baltic states with respect to EU enlargement. ${ }^{28}$ Emigration increased rapidly after the Baltic states joined the EU in 2004. It was further boosted during the financial crisis in 2009-2011, especially from Lithuania and Latvia. Censuses in these countries showed that at least 213,000 left Latvia between 2000-2011, while 615,000 left Lithuania between 1990-2011. ${ }^{29}$ The direction was towards the West. Furthermore emigration from the Baltics was represented as involving a substantial number of young and low-skilled workers. ${ }^{30}$ 'Old' member states in the EU received large numbers of migrants from the Baltic countries, with the UK being the most important destination for Latvia and Lithuania, while most Estonians went to neighbouring Finland. Mainly young, not likely to be welfare recipients, yet working for wages which were relatively low compared to those of the local workforce, these new European migrants were a gain for EU core economies. Hence EU enlargement clearly contributed to the growth potential and output of the 'old' member states, while the human capital consequences in the Baltics remain yet to be explored in depth. ${ }^{31}$ Moreover, even during the global economic and financial crisis, which hit the Baltic states, especially Latvia, very hard, new waves of migrants continued to make a solid economic contribution to their various destinations. $^{32}$ Namely, they were not a burden to the recipient country, while they were a human loss to rapidly depopulating regions of origin.

Albania, and Kosovo, but for very different reasons and with contrasting migration dynamics, are the most extreme cases of emigration from the Western Balkans after the collapse of the communist regimes. The Kosovo war unleashed large-scale refugee movements in the 1980s$1990 \mathrm{~s} .{ }^{33}$ In the late 2000 s this resulted in the situation where every third household in Kosovo has migrant family members, with consequent dependence on remittances and a household economy and family-social relations strongly linked to transnational ties abroad. ${ }^{34}$. The Albanian case vies with Moldova for being the European country where the relative impact of post-communist mass migration has been relatively greatest: according to World Bank figures, a 'stock' of Albanians living abroad of about 1.4 million, equivalent to nearly half of the Albanian resident population of just less than 3 million. ${ }^{35}$ But also Serbia, Bosnia and Herzegovina, and the newly-named Republic of Northern Macedonia continue to show high emigration levels, albeit with strong signs of decline of emigration at the beginning of the 21 st century.

In the 2000s representations of the Balkan model of migration have tended to portray stages. For instance, the fact that quantitatively emigration flows from Serbia tend to be predominantly males is interpreted that migration is still in early stages. ${ }^{36}$ Later studies were also analyzing how emigration from the Balkans normalized and matured in its trends, representing the positive dynamics of broader stabilization processes in the region. Accordingly, a stage-type of representation of migration reveals novel aspects, especially with respect to how migration can contribute to processes of peripheralization. Similarly, forecasts of future emigration trends as 
continuous contribute to such 'peripheralist' representations, whether emigration is caused by push factors of an economic, political, or nationalistic nature, or other factors. ${ }^{37}$ Migrants from postsocialist countries are also represented as 'learning migrants', engaged in capitalist learning processes, both those searching for better economic opportunities and those facing the harsher reality of unemployment. ${ }^{38}$

According to the World Bank, labour markets in the Western Balkan countries are characterized by low employment rates and high unemployment by European standards. Emigration, depopulation, and deindustrialization lead to representations of a kind of 'superperiphery' in the Western Balkans, ${ }^{39}$ while the Baltic states of Latvia and Lithuania are more seen as semi-periphery, with Estonia striving towards the status of a Nordic core economy. ${ }^{40}$ Clearly, emigration trends play a role in representations of both cores and peripheries. But emigration, together with low birth rates, go hand-in-hand with another peripheralization process, namely depopulation, whose effects are generally less thoroughly researched than those attributed more directly to migration. The representation that such modes of migration imply is that these countries are not doing well economically, experiencing brain drain and youth drain, which further lead to depopulation and rapid ageing.

\section{Depopulation and 'brain drain'}

In the Baltic discourses, but not in Estonia, depopulation trumps 'brain drain'. Both are present in Western Balkan discourses, but here there is more emphasis on 'brain drain'.

Table 1. Population: Western Balkans and Baltics (millions)

\begin{tabular}{|c|c|c|}
\hline Country & 2005 & 2015 \\
\hline Albania & 3.01 & 2.88 \\
\hline $\begin{array}{l}\text { Bosnia and } \\
\text { Herzogovina }\end{array}$ & 3.78 & 3.54 \\
\hline Croatia & 4.44 & 4.20 \\
\hline Kosovo & 2.00 & 1.80 \\
\hline Montenegro & 0.613 & 0.622 \\
\hline $\begin{array}{l}\text { The Republic of } \\
\text { Northern Macedonia }\end{array}$ & 2.04 & 2.08 \\
\hline Serbia & 7.5 & 7.10 \\
\hline Estonia & 1.36 & 1.32 \\
\hline
\end{tabular}




\section{Latvia}

Lithuania
2.30

3.41
1.98

2.91

Sources: European Commission key figures on enlargement countries, 2017; Statistical offices of Estonia, Latvia and Lithuania

For comparative reasons, population trends in both regions are presented in Table 1. This shows widespread and notable population decline in most of the countries listed. Slight increases of population are recorded only in Montenegro and The Republic of Northern Macedonia for the ten years 2005-2015. Moreover, much of the emigration took place before these years and thus the most recent decade simply continues the declining trend already apparent in the early 1990s. In relative terms, there has been an at-least $12-16 \%$ population decline in Latvia and Lithuania due to emigration since the 1990s. But apart from statistical representation, depopulation is 'felt' across much of the Baltic region, where emptying towns and villages are observed away from the national capitals and other main cities. ${ }^{41}$ Hence peripheralization has a 'structure of feeling', which goes above and beyond the picture yielded by scientific portrayals and periodic census data, which can be several years out-of-date.

According to Eurostat data published in 2018, population decline continues rapidly and the Baltic and Balkan countries are in leaders in this trend: the steepest decrease was in Lithuania 13.8 per 1,000 residents per year, followed by Croatia -11.8 , and Latvia -8.1 . All figures are for the year 2017. And yet, Estonia's population increased by 2.7 per 1,000 residents. However, Estonia's specific situation is related to 'commuter migrants' between Estonia and nearby Finland, who are not always counted into the statistics of emigration. While on average the EU population grew by 2.1 per thousand in 2017, decline was observed in many Southern and South-Eastern member-states: Bulgaria (-7.3 per 1,000 residents), Romania (-6.2), Greece (-2.7), Hungary (-2.0), Portugal (-1.8), and Italy $(-1.7){ }^{42}$

Depopulation is generally linked to weak development, especially in Western Balkan discourses, as the latest surveys of graduate migration and intentions to leave show. ${ }^{43}$ Suggestions to boost jobs in order to tackle structural brain drain due lack of opportunities are highly visible in Balkan representations of this issue. ${ }^{44}$ They are less apparent in the Baltics despite broadly similar structural conditions. Brain drain has been an ongoing concern for the Balkans for several decades now, while the broader emigration trend changed around the 2000s when also more less-skilled and older people emigrated. ${ }^{45}$

In the Baltics, more focus is on the issue of skills-mismatch and the record emigration; for Lithuania, this is related to the over-education of transferable skills of Lithuania's workforce. ${ }^{46}$ 'Brain drain' as such was less evident in the Baltic scientific discourse on migration, overtaken instead by skills-mismatch and the deskilling of Baltic migrants already working abroad. ${ }^{47}$ During the economic crisis in the Baltics, a strongly neoliberal approach was taken, representing emigration as a rational choice: to put it simply, if there are reduced chances to get a job at home, then go abroad. However, when analysing 'brain drain' through educational differences among emigrants and those who stayed put, Estonian migration scholars came to the conclusion that there was no significant brain drain after the EU enlargement. ${ }^{48}$ Differences, however, have been found in 
relation to return migration intentions and integration levels in the host countries; ethnic Russians tend to express lower return migration intentions compared to ethnic Estonians. ${ }^{49}$ Similar trends have been found also in Latvia. ${ }^{50}$

\section{Transit migration: the very Western Balkan 'problem'}

For some time the dominant representations within the Balkan field of migration research were concerned with wars, nationalism, displacement and geographical mobility rights. ${ }^{51}$ This creates a particular mode of peripheralization: the Western Balkans as periphery outside the 'club' of fortress Europe, and the construction of regional stability needs in terms of migration. ${ }^{52}$ Dominated by discursive representations of 'illegal migration' and conditionality for institutions in the region to deal with it, ${ }^{53}$ transit migration poses a special additional challenge to the above-discussed processes of East-West migration, depopulation and 'brain drain'. While emigration has clearly been associated with weak development in the Western Balkan region, discourses of 'crisis' in the Western Balkans have seen particularly linked to 'refugee crises': in the 1980s and 1990s as 'exodus' from the Balkans, and in 2015 as a transit route via the Western Balkans. ${ }^{54}$ It is estimated that over a million migrants and asylum seekers transited the Western Balkan route in 2015 and 2016. ${ }^{55}$ The flanking peripheralization effect is that these processes lead towards restrictive migration policies and requirements to increase capacities to deal with migration in Western Balkan countries which have yet to receive any specific time-frame for potential EU accession. Moreover, this mode of peripheralization - constructed as a strategic geopolitical location for migration/refugee routes along with considerable ongoing emigration and weak development gives rise to discourses on the lack of capacity and even willingness of the Western Balkan countries to deal with requirements to process asylum applications. ${ }^{56}$

Conversely, a major decline in irregular migration implies the effective willingness to control migration along with the capacity to fight organized crime related to some irregular migration processes, and thus move away from a periphery-as-transit migration discourse. ${ }^{57}$ Prevention and control of irregular migration were among the pre-accession objectives in the Western Balkans in the late 2000s. ${ }^{58}$ Migration control is also a factor which leads towards the EU (or away from it if unsuccessful); hence prepheralization is constructed as a mode of lack of 'Europeanization' trends. ${ }^{59}$

\section{Return migration}

While in the Balkans emigration was possible throughout the $20^{\text {th }}$ century, except Albania, mass labour emigration from the Baltics began again only in the 1990s, accelerating sharply after joining the EU in 2004. While some 'guest-workers' from Balkans did return in the 1970s and 1980s, as already mentioned, some of them left again, unwilling or unable to adjust back to socialist rule. But return took place also among more recent migrants, including refugees from Bosnia. ${ }^{60}$ Return in later life, post-retirement, also is a trend, if not yet large in numbers in the Balkans. 
But returns to peripheries or semi-peripheries are more complex than theories which take the core-periphery imaginary as a standard of migration dynamics have often imagined. The Balkans, again, are a good example. During the severe Greek economic crisis, return migration to Albania also occurred, on a larger scale than from Italy or the 'core' economies in Europe or elsewhere where Albanians had emigrated. ${ }^{61}$ Greece, along with Italy, host most of the Albanian migrants, partly related to geographic proximity, but many Albanian men lost their jobs during the crisis in Greece. Many of them returned to Albania to explore work opportunities there. ${ }^{62}$ Crisis-induced returns from Greece to Albania signify the necessity for a more nuanced analysis of how migration and return migration flows are embedded within core-periphery dynamics. In this particular case, if we class Albania as periphery and Greece as semi-periphery, then migration from the former to the latter creates a fragile dependency which is exposed when the semi-peripheral country stumbles into a deep crisis. ${ }^{63}$

It has been noted that the countries of Eastern Europe seems to be slower than other European countries not only in return trends but also in attracting immigration flows. ${ }^{64}$ Accordingly, peripheralization, seen from the migration perspective, persists over time in these regions. The exception is Estonia, where immigration has overtaken emigration in 2017. Return to the Baltics is still rarely discussed in scientific texts on migration. When the issue of return has been mentioned in international publications, the focus has been on high aspirations to return and high selectivity towards young and entrepreneurial talent in Lithuania ${ }^{65}$ and Estonia, ${ }^{66}$ with somewhat more cautious discourses on the actual potential to transfer skills back home in Latvia. ${ }^{67}$ Quality of life in the Baltics upon return can indeed be somewhat higher, but mainly for certain groups, usually the higher skilled and those working in highly demanded and well-paid professions. ${ }^{68}$

The young and highly skilled aspire to return to Serbia too, as Prelec's research demonstrates in this special issue. ${ }^{69}$ However, they are highly critical towards nationalistic stances in their country of origin, which leaves a gap between their high aspirations and the actual decisions to remain abroad and engage in home politics through transnational links, such as external voting.

The transnational migration perspective, where permanent return is not envisaged as the primary option, is gradually emerging in both the Balkans ${ }^{70}$ and the Baltics ${ }^{71}$. This approach can also be seen in a variety of diaspora initiatives in both regions. There is no lack of initiatives for socalled global leaders, ${ }^{72}$ diaspora youth, talent return migration and work opportunities for high skilled. $^{73}$ Civic Innovation Incubators, global diaspora strategies, ${ }^{74}$ high-level political representation - all these are rather similar in all countries but still with rather minimal actual results to report.

The impact of the emigration of skilled people on development in the Western Balkans still remains to be explored from varied perspectives, including transnational ties which may include, but not necessarily result in return migration. ${ }^{75}$ Yet there are alarming voices that maintain that 'knowledge emigration' could have more adverse future effects on development than overall emigration. On the other hand, talent migration, if there are strong diaspora and return incentives, can be even beneficial if ties with the country of origin are maintained. ${ }^{76}$ 


\section{Conclusions}

Firstly, the construction of emigration, represented scientifically as the East-West model for several decades, reinforces the representation of peripheries. As such, this process is a social construction of peripheralization. This is not to say that there are no 'real facts' about emigration - this was not the main point of the paper. My argument is that socially constructed representations contribute to the ways in which we perceive, comprehend and continue to represent peripheralization.

Secondly, the representation of depopulation adds even more to the perception of continuous peripheralization in these regions, along with a narrowed future development potential due to brain drain. The latter, however, is represented in more varied ways in the Balkans and Baltics. Estonia stands out as an example where brain drain is actually not perceived as an emigration-induced problem.

These seemingly straightforward findings require a theoretical discussion as well. Peripheralization, unlike the simple definition of peripheries as territorial units ranked lower than cores, is a process and creation of perception. With respect to regional peripheralization, it is obvious how representation matters. Both the Balkans and the Baltics have been historical peripheries within empires and in socialist unions during the $20^{\text {th }}$ century, with the partial exception of Serbia which, as part of Yugoslavia, could be considered as its centre of power. As contemporary peripheries these regions can be relegated vis-à-vis the European Union with the Baltics being members since 2004, while most of the Western Balkan countries have not yet received a concrete time-table for joining the EU (with exception of Croatia, which joined smoothly with rather little public notice in 2013). What is important in terms of peripheralization as a process, is how some countries, individually and not as regions, are represented as moving away from a periphery or semi-periphery, as with the case of Estonia. Paasi's questions of 'who and what constructs regions, through what associations/networks and for what purposes?'77 are central here, using migration as a lens through which we can think about peripheralization.

The response from my findings is that making a threshold turn when net immigration replaces net emigration, is a milestone event in the ways through which migration matters in the representation of countries. Such predictions that successful fulfilling of the required conditions for EU accession would make countries attractive to immigrants are widespread. Yet, this has not been the case in the Baltics so far, and even in the case of Estonia it is unclear whether EU accession as such makes the country more attractive for immigration. The opposite is clearer: nationalistic politics deter both return migration and immigration. Staunch opposition to immigration and emphasis on diaspora policies and the return of 'our people' - co-ethnics - reveal a mode of peripheralization which stems from within countries rather than being externally constructed.

As states, the Western Balkans and the Baltics reveal considerable diversity, individualization, and the deliberate choosing of a regional affinity discursively; again, with Estonia as a stand-out example, representing itself the most vocally as a Nordic, rather than a Baltic state. But there are also similarities, especially due to the geopolitical positioning of these regions as 'margins' of Europe. For the Western Balkans it is especially strong through the mode of transit migration which represents the region as a buffer outside the 'fortress' EU and yet with limited capacities and 'willingness' to deal with asylum procedures. Recent transit migration via the Western Balkans represents the case of a specific challenge. 
I want to conclude with two perspectives which could make a difference in reimagining peripheralization processes through migration. Firstly, the representation of modes of migration takes us beyond current understandings that the periphery as such can remain a relatively stable scientific concept, even if 'never fully complete and stable'. ${ }^{78}$ The migration perspective not only adds a factor on how peripheralization can be measured and interpreted; moreover, it adds a dynamic element and destabilizes the otherwise relatively stable thinking on spatial units. And secondly, transnational and relational perspectives necessitate that studies of migration to and from relatively small states and territories be placed on equal footing with those of core states and core languages. When theories and research emerge from such places, and not only about these places, we may reimagine cores and peripheries in a different light.

\section{Disclosure statement}

No potential conflict if interest was reported by the author.

\section{Notes on contributor}

Aija Lulle is a migration scholar and Lecturer in Human Geography at Loughborough University, UK. She has previously worked at the Universities of Latvia, Sussex (UK) and Eastern Finland.

\section{Notes}

1 For a rare exception see R. King, J. Vullnetari, A. Lulle and E. Cela, 'Contrasts in ageing and agency in family migratory contexts: a comparison of Albanian and Latvian older migrants,' in E. Palenga-Möllenbeck and M. Kilkey (eds) Family Life in an Age of Migration and Mobility: Global Perspectives Through the Life Course, Palgrave Macmillan, Basingstoke, 2016, pp. 261-286.

2 A. Paasi, 'Regions are social constructs, but who or what "constructs" them? Agency in question', Environment and Planning A, 42(10), 2010, pp. 2296-2301.

3 Ibid., p. 2298.

4 L. Wolff, Inventing Eastern Europe: The Map of Civilization on the Mind of the Enlightenment, Stanford University Press, Stanford, 1994.

5 See R. King, R. Skeldon and J. Vullnetari, Internal and International Migration: Bridging the Theoretical Divide. University of Sussex, Sussex Centre for Migration Research, Working Paper No. 52, 2008.

$6 \quad$ Paasi, op. cit, pp. 2297, 2301.

7 Z. Krisjane and M. Berzins, 'Post-socialist urban trends: new patterns and motivations for migration in the suburban areas of Rīga, Latvia' Urban Studies, 49(2), 2012, pp. 289-306. 
8 See T. Lang, S. Henn, W. Sbignev and K. Ehrlich, Understanding Geographies of Polarization and Peripheralization: Perspectives from Central and Eastern Europe and Beyond. Palgrave Macmillan, Basingstoke, 2015, p. 12.

9 W. Bartlett and I. Prica, 'Debt in the super-periphery: the case of the Western Balkans', Third World Thematics: A TWQ Journal, 2018, DOI: 10.1080/23802014.2017.1438850

10 See J. P. Cassarino, 'Theorising return migration: the conceptual approach to return migrants revisited', International Journal on Multicultural Societies, 6(2), 2004, pp. 253-279.

11 For the most complete account of European core-periphery dynamics in the context of migration see R. King, 'Migration in Southern Europe - a centre-periphery dynamic?' in M. Baumeister and R. Sala (eds) Southern Europe? Italy, Spain, Portugal and Greece from the 1950s to the Present day, Campus Verlag, Frankfurt and New York, 2015, pp. 139-169. See also R. King, A. Lulle, V. Parutis and M. Saar, 'From peripheral region to escalator region in Europe: young Baltic graduates in London', European Urban and Regional Studies, 25(3), 2018, pp. 284-299.

12 A.G. Frank, Capitalism and Underdevelopment in Latin America. Monthly Review Press, New York, 1969.

13 I. Wallerstein, The Modern World-System, Academic Press, New York, 1974.

14 D. Seers, B. Schaffer and M.-L. Kiljunen (eds.), Underdeveloped Europe: Studies in CorePeriphery Relations, Harvester Press, Hassocks, 1979.

15 P. Selwyn, 'Some thoughts on cores and peripheries', in D.Seers, B. Schaffer and M.-L. Kiljunen (eds.), Underdeveloped Europe: Studies in Core-Periphery Relations, Harvester Press, Hassocks, 1979, pp. 35-43.

16 S. Beetz, S. Huning and T. Plieninger, 'Landscapes of peripherization in North-Eastern Germany's countryside: new challenges for planning theory and practice', International Planning Studies, 13(4), 2008, pp. 305.

17 M. Kuus, 'Places of lower rank: margins in conversations', Political Geography, 37(A1-2), 2013, pp. 30-32.

18 For a recent detailed study of the Albanian brain drain see I. Gedeshi and R. King, Research Study into Brain Gain: Reversing Brain Drain with the Albanian Scientific Diaspora, Center for Economic and Social Studies, Tirana, report prepared for UNDP.

19 D. J. Galbreath and J. W. Lamoreaux, 'Punching above your weight? The Baltic States as “small states” and the European neighbourhood policy?' In Z. Ozolina and N. Muiznieks (eds) Uncertain Transformations. New Domestic and International Challenges, Riga, LU Akdemiskais Apgads, 2007, pp. 21-33; M. Todorova, Imagining the Balkans, Oxford University Press, Oxford, 2009.

20 M. Saar, The Answers You Seek Will Never be Found at Home: Reflexivity, Biographical Narratives and Lifestyle Migration among Highly Skilled Estonians, PhD dissertation, Södertörns Högskola, Huddinge, 2017.

21 Paasi, op. cit. 2010; see also D. Light and C. Young, 'European Union enlargement, postaccession migration and imaginative geographies of the "New Europe": Media discourses in Romania and the United Kingdom', Journal of Cultural Geography, 26(3), 2009, pp. 281303. 
22 See H. Bauder and G. Gilbert, 'Representations of labour migration in Guatemalan and American media', ACME: An International E-Journal for Critical Geographies, 8(2), 2009, p. 283; also H. Bauder, Landscape and scale in media representations: the construction of offshore farm labour in Ontario, Canada', Cultural Geographies, 12(1), 2005, pp. 41-58. D. Ljuboja, Migration Processes in the Balkans in the 20th and 21st Centuries, 2015. $<\mathrm{http}$ ://www.cirsd.org/en/young-contributors/migration-processes-in-the-balkans-in-the20th-and-21st-centuries $>$ (accessed 15 July 2018). 269-356.

Ibid.

R. King, 'Albania as a laboratory for the study of migration and development', Journal of Southern Europe and the Balkans, 7(2), 2005, pp. 133-155.

For more details see the collection of papers in J. Vullnetari and R. King (eds) 'Twenty Years of Albanian Migration', Journal of Balkan and Near Eastern Studies, 13(3), 2011, pp.

R. King, E. Uruçi and J. Vullnetari, 'Albanian migration and its effects in comparative perspective', Journal of Balkan and Near Eastern Studies, 13(3), 2011, pp. 269-286.

J. Kielyte and D. Kancs, 'Migration in the enlarged European Union: empirical evidence for labour mobility in the Baltic states', Journal of Baltic Studies, 33(3), 2002, pp. 259-279.

Latvia Population Census, $2011<\mathrm{https} / /$ www.csb.gov.lv/en/statistics/statistics-bytheme/population/census>; Lithuania Population Census, 2011

$<$ https://osp.stat.gov.lt/en/gyventoju-ir-bustu-surasymail $>$

G. Engbersen and J. Jansen, 'Emigration from the Baltic States: Economic impact and policy implications', In OECD, Coping with Emigration in Baltic and East European Countries, OECD, Paris, 2013, p.13.

See F. Keereman and I. Szekely (eds) Five Years of an Enlarged EU: A Positive Sum Game, Springer-Verlag, Berlin and Heidelberg, 2010, pp. 63-94.

A. Lulle, 'Baltic triplets? Out-migration and responses to crisis', Regional Formation and Development Studies, 3(11), 2013, pp. 135-145; also A. Zaiceva and K.F. Zimmermann, 'Returning home at times of trouble? Return migration of EU enlargement migrants during the crisis', In M. Kahanec and K.F. Zimmermann (eds) Labor Migration, EU Enlargement, and the Great Recession. Springer, Berlin and Heidelberg, 2016, pp. 397-418.

J. Reineck, The Past as Refuge: Gender, Migration, and Ideology among Kosova Albanians, $\mathrm{PhD}$ dissertation, University of California, Berkeley, 1991.

Diaspora as a Driving Force for Development in Kosovo: Myth or Reality? Forum for Democratic Initiatives, Gjakove, Kosovo, 2009.

$<$ https://www.eda.admin.ch/dam/deza/en/documents/laender/resource-183043_EN.pdf $>$ (accessed 21 July 2018); J. Möllers, W. Meyer, S. Xhema, D. Traikova and G.

Buchenrieder, 'Cognitive constructs and the intention to remit' Journal of Development Studies, 51(10), 2015, pp. 1341-1357.

See Migration and Remittances Factbook, World Bank, Washington DC, 2011, pp. 54, 180.

M. Kupiszewski, A. Kicinger, D. Kupiszewska and E.F. Flinterman, Labour Migration

Patterns, Policies and Migration Propensity in the Western Balkans, , International

Organization for Migration, Budapest, 2009, pp. 12-13. 
37 F.W. Carter, 'Ethnicity as a cause of migration in Eastern Europe,' GeoJournal, 30(3), 1993, pp. 241-248.

38 B. Balli, 'From communist past to capitalist present: Labour market experiences of Albanian immigrants in Greece', Journal of Balkan and Near Eastern Studies, 13(3), 2011, pp. 323 337.

39 W. Bartlett, 'Economic development in the European super-periphery: Evidence from the Western Balkans', Economic Annals, 54(181), 2009, pp. 21-44.

40 King, Lulle, Parutis and Saar, op.cit.

41 T. Lukic, R. Stojsavljevic, B. Durdev, I. Nad and B. Dercan, 'Depopulation in the Western Balkan countries', European Journal of Geography, 3(2), 2012, pp. 6-23; D. Dzenovska, Aizbraukšana un tukšums Latvijas laukos: Starp zudušām un iespējamām nākotnēm. Biznesa Augstskola Turība, Riga, 2012.

42 Eurostat, population trends, $<$ http://ec.europa.eu/eurostat/web/products-eurostat-news/$/$ WDN-20180711-1 inheritRedirect $=$ true \&redirect $=\% 2 \mathrm{Feurostat} \% 2 \mathrm{~F}>($ accessed 21 July 2018).

43 I. Gedeshi, The Global Crises and Emigration - Monitoring a Key Transmission Channel to the Albanian Economy, UNDP/IOM/WB Albania, 2010.

44 D. Kovtun, A. Mayer Cirkel, Z. Murgasova, D. Smith and S. Tambunlertchai, Boosting Job Growth in the Western Balkans, IOM, 2014.

$<$ https://www.imf.org/en/Publications/WP/Issues/2016/12/31/Boosting-Job-Growth-in-theWestern-Balkans-41284> (accessed 21 July 2018).

45 E. Germenji and L. Milo, 'Return and labour status at home: evidence from returnees in Albania', Southeast European and Black Sea Studies, 9(4), 2009, pp. 497-517.

46 Z. Norkus, On Baltic Slovenia and Adriatic Lithuania: A Qualitative Comparative Analysis of Patterns in Post-Communist Transformation, CEU Press, Budapest, 2012.

47 M. Hazans and K. Philips, 'The post-enlargement migration experience in the Baltic labor markets', in M. Kahanec and K. F. Zimmermann (eds.), EU Labor Markets after PostEnlargement Migration, Springer, Berlin and Heidelberg, 2010, pp. 255-304; R. Eamets, 'Employment, labour market flexibility and the economic crisis in the Baltic states', In Estonian Human Development Report, Eesti Koostoo Kogu, Tallinn, 2011, p. 74.

48 K. Anniste, T.Tammaru, E. Pungas and T. Paas, Emigration after EU Enlargement: Was There a Brain Drain Effect in the Case of Estonia? Working Paper No. 87, University of Tartu, 2012.

49 K. Anniste and T. Tammaru, 'Ethnic differences in integration levels and return migration intentions: A study of Estonian migrants in Finland', Demographic Research, 30(1), 2014, pp. 377-412.

50 S. Aptekar, 'Contexts of exit in the migration of Russian speakers from the Baltic countries to Ireland' Ethnicities, 9(4), 2009, pp. 507-526.

51 M.H. Yavuz and I. Blumi, War and Nationalism: The Balkan Wars 1912-1913, and their Sociopolitical Implications, The University of Utah Press, Utah, 2013.

52 A. Geddes and A. Taylor, 'In the shadow of fortress Europe? Impacts of European migration governance on Slovenia, Croatia and Macedonia', Journal of Ethnic and Migration Studies, 
42(4), 2016, pp. 587-605; N. Tzifakis, 'EU's region-building and boundary-drawing policies: the European approach to the Southern Mediterranean and the Western Balkans', Journal of Southern Europe and the Balkans, 9(1), 2007, pp.47-64.

53 F. Trauner, 'From membership conditionality to policy conditionality: EU external governance in South Eastern Europe', Journal of European Public Policy, 16(5), 2009, pp. 774-790.

54 J. Sardelic, From Temporary Protection to Transit Migration: Responses to Refugee Crises along the Western Balkan Route, European University Institute, Florence, RSCAS Working paper 35, 2017.

55 J. Arsenijević et al. (12 authors), 'A crisis of protection and safe passage: violence experienced by migrants/refugees travelling along the Western Balkan corridor to Northern Europe', Conflict and Health, 11(6), 2017, pp.1-9.

56 N. Kogovšek Šalamon, 'Asylum systems in the Western Balkan countries: current issues', International Migration, 54(6), 2016, pp. 151-163.

57 M. Baldwin-Edwards, 'Sustainable development and emigration: the contemporary Balkans and the European Union,' SEER: Journal for Labour and Social Affairs in Eastern Europe, 7(1), 2004, pp. 9-14.

58 F. Trauner, EU Justice and Home Affairs Strategy in the Western Balkans: Conflicting Objectives in the Pre-Accession Strategy. CEPS Working Document No. 259, 2007 $<$ http://aei.pitt.edu/7383/2/7383.pdf> (accessed 21 July 2018). S. Kacarska, Europeanisation Through Mobility: Visa Liberalisation and Citizenship Regimes in the Western Balkans. CITSEE Working Paper 11, 2011.

60 A. H. Stefansson, 'Homes in the making: property restitution, refugee return, and senses of belonging in a post-war Bosnian town', International Migration, 44 (3), 2006, pp. 115-139.

61 R. Panagiotou, 'The Greek crisis as a crisis of EU enlargement: how will the Western Balkans be affected?', Southeast European and Black Sea Studies, 13(1), 2013, pp. 89-104.

62 E. Caro, "I am an emigrant in my own country": a profile of Albanian returnees from Greece" Journal of Science and Higher Education Research, 1 (1), 2016, pp 9-25.

63 D. Bechev, The Periphery of the Periphery: The Western Balkans and the Euro Crisis, European Council of Foreign Relations, 2012.

$<$ https://www.ecfr.eu/publications/summary/the_periphery_of_the_periphery_the_western_ balkans_and_the_euro_crisis $>$ (accessed 21 July 2918).

64 M. Okolski, Europe in movement: Migration from/to Central and Eastern Europe, CMR Working Papers 22/80, 2007.

65 E. Barcevičius, 'How successful are highly qualified return migrants in the Lithuanian labour market?’ International Migration, 54(3), 2015, pp. 35-47.

66 Saar, op.cit.

67 R. King, A. Lulle and L. Buzinska, 'Beyond remittances: knowledge transfer among highly educated Latvian youth abroad' Sociology of Development, 2(2), 2016, pp. 183203.

68 Saar, op.cit. 
69 T. Prelec, 'The Serbian diaspora's political views: A study on the 2017 Serbian presidential election', Journal of Balkan and Near Eastern Studies, this issue.

70 See for instance, S. Bozic, 'Is there a Croatian diaspora in Europe? From "Gastarbeiters" to transmigrants and ethnics', Croatian Studies Review, 8, 2012, pp. 117-134; S. Bozic and S. Kuti, 'New international borders old social spaces: Transnational migrant networks across the boundaries of post-socialist Croatia', Österreichische Zeitschrift für Soziologie / Austrian Journal of Sociology, 41(4), 2016, pp. 409-426.

71 A. Lulle and L. Buzinska, 'Between a "student abroad" and "being from Latvia": inequalities of access, prestige, and foreign-earned cultural capital', Journal of Ethnic and Migration Studies, 43(8), 2017, pp. 1362-1378.

72 Programmes for Lithuanian emigrants, $<\underline{\text { www.kurklt.lt/en }>\text {; }}$

$<$ http://www.enterpriselithuania.com/en/> (accessed 21 July 2018).

73 Talents Back Home!, <www.workinestonia.ee> (accessed 21 July 2018).

74 Croatian Diaspora Congress - Zagreb 2014. $<$ http://www.hrvatski-iseljenickikongres.org/en/ $><$ http://www.domovod.info/forum.php $>$ (accessed 21 July 2918).

75 E. Germenji and L. Milo, 'Migration of the skilled from Albania: Brain drain or brain gain?', Journal of Balkan and Near Eastern Studies, 13(3), 2011, pp. 339-356; and more broadly R. King, M. Frykman, and J. Vullnetari (eds) Migration, Transnationalism and Development in South-East Europe and the Black Sea Region. Routledge, London and New York, 2017.

76 D.Kancs and J. Kielyte, J. (2010). Education in the East, emigrating to the West? European Review, 18(2), 2010, pp. 133-154.

77 Paasi, op.cit.

78 Ibid, p. 2229. 